Журба С. С., кандидат філологічних наук, доцент кафедри української та світової літератур ДВНЗ «Криворізький державний педагогічний університет»

\title{
ЖАНРОВІ МОДИФІКАЦІї РОМАНУ «ВІЛЬНИЙ СВІТ» Т. БЕЛІМОВОї
}

У статті досліджено жанрову своєрідність твору Тетяни Белімової «Вільний світ». Вказано, що своєрідність авторського художнього мислення реалізується через модифікацію жанру: роман-хроніка, роман-сімейна сага, роман-спогад, роман-пам'ять. Зроблено спробу простежити метафору «вільного світу» через образи персонажів та на історіософському рівні.

Ключові слова: жанр, роман-спогад, роман-хроніка, роман-сімейна сага, персонаж, часопростір. 
В статье исследуется жанровое своеобразие произведения Татьяны Белимовой «Свободный мир». Указано, что своеобразие авторского художественного мыиления реализуется через модификацию жанра: роман-хроника, роман-семейная сага, романвоспоминание, роман-память. Сделана попытка проследить метафору "свободного мира» через образы персонажей, и на историософском уровне.

Ключевые слова: жанр, роман-воспоминание, роман-хроника, роман-семейная сага, персонаж, пространство, время.

In the article is researched the genre originality of the novel by Tetyana Belimova "Free World". It is specified that the peculiarity of author's artistic thinking is realized through the modification of the genre: romance-chronicle, romance-family saga, romance-memories, romancememory. An attempt is made to trace the metaphor of the "free world" as an image of the characters, both at the philosophical level.

Keywords: genre, romance-memoir, romance-chronicle, novel-family saga, character, time space.

Сучасна постмодерна література демонструє поліфонічність тексту на структурному та історіофілософському рівні, деструкцію тексту, інтертекстуальність, карнавалізацію текстового простору, гру 3 текстом і читачем, суміш різних жанрів, про що засвідчили своїми творами українські письменники - Ю. Андрухович, О. Ірванець, В. Даниленко, Любко Дереш, Дара Корній, В. Лис, Марія Матіос, Галина Пагутяк, В. Шкляр та інші.

Зростання жанрових трансформацій у епоху постмодернізму експліковане апробацією задекларованих категорій, пов'язане 3 необхідністю зміни авторської настанови на дефініцію жанру, техніку оповіді, міметичну спрямованість, рецептивну естетику, авторську гру, зміну масштабу розвитку подій.

До проблеми модифікації роману як жанру у сучасному вітчизняному літературознавстві звертаються О. Боярчук («Експериментальна проза 20-х років XX століття: жанрово-стильові модифікації»), Л. Ковальчук («Биографическая проза: Основные жанровые модификации»), Н. Копистянська («Жанр, жанрова система у просторі літературознавства»), Т. Кушнірова («Проблемні питання типології роману в літературознавстві»), які у дослідженнях вивчають питання архітектоніки, нарації, типології, трансформації, динаміки та функціонування літературних жанрів в історичній проекції. Т. Бовсунівська у монографії «Жанрові модифікації сучасного роману», аналізуючи сучасні романи західних та українських письменників, 
уточнює основні категорії жанрології, зокрема поняття «жанрової модифікації», вказуючи, що це «відповідним чином структурована система ідеологем художнього мислення. Вона може визначатися тільки у кореляиї 3 ідеологічними прочесами доби» [Бовсунівська 2015:27].

Письменники-постмодерністи не утримують роман в межах існуючої жанрової системи, тому відбуваються певні «мутації», витворюється індивідуально-авторська жанрова форма. Жанровий синктеризм характерний для творів Тетяни Белімової. Письменниця за роман «Київ.UA» у 2013 році вона здобула третю премію, а в 2014 - отримала першу премію за твір «Вільний світ» в номінації «Романи». Прозовий доробок двічі «коронованої» письменниці невеликий - оповідання, новели, збірка есеїстики, романи, проте знайшов свого критика. В основному це рецензії, огляди, відгуки на роман «Вільний світ» Аліни Акуленко, Анни Грогорової, А. Кокотюхи, А. Ткаченка, Софії Філоненко.

Мета статті - дослідити жанрові різновиди роману «Вільний світ», своєрідність авторського художнього мислення, що реалізується через модифікацію жанру: роман-хроніка, сімейна сага, роман-спогад, роман-пам'ять, біографічний роман.

Сучасний літературний процес характеризується індивідуальноавторським наративним дискурсом, прагненням деканонізації жанру та стильовими пошуками, подоланням межі між масовою та інтелектуальною літературою. Оновлення романного жанру спостерігається на фабульнокомпозиційному рівні: відкритість, текстуальне «декодування відповідно до правил $i$ законів гри» (Ю. Ковалів), інтертекстуальність, метанаративність, синкретизм, жанровий еклектизм, та відповідає вимогам до постмодерністської структури твору.

Визначаючи жанрові особливості роману «Вільний світ» Тетяни Белімової, дослідники у рецензіях тільки означили його різновиди: «романхроніка, роман-світлина, роман-щоденник, роман-спогад» (Аліна Акуленко), «роман-обрис, сімейна сага, роман-пам'ять» (Софія Філоненко). Жанрові 
дефініції цього твору доповнює й сама авторка - «історичний роман-образ», постулюючи право творця декларувати власне авторський жанровий різновид.

Характерною особливістю роману $є$ високий рівень документальності, детермінований історичною достовірністю подій, відображенням життя і реалій від 30-х років XX століття до сьогодення, відтворення життя, побуту та лексики (мови) героїв. Письменниця відверто декларує у тексті ознаки хроніки, документальності, що виступають жанротворчими чинниками для визначення жанрової дефініції твору. Історичне тло роману окреслено подіями від 30-х років XX століття i до наших днів. Фрагментарно, як у кінострічці, перед читачем постають основні суспільно-політичні події: голодомор 30-х років, Друга світова війна, повоєнна відбудова держави, тоталітарний устрій СРСР, період відбудови української державності. Персонажі роману, з одного боку, постають безпосередніми свідками реальних подій, а 3 іншого, входять у світ іншого творця власної історії. Авторка подає історію у двох зрізах: історія родини - історія держави (СРСР, України), що накладаються одна на одну. У романі, хронологія якого охоплює події трагічної історії нашої держави 1932-33 років, письменниця розвінчує міф про знищення українського селянства владою під час голодомору, зазначаючи, що «відбувалося цуе руками українців» (Т. Белімова), своїми ж односельцями, малописьменними, несвідомими, «за вказівкою згори. <..> Невже вони не розуміли, щзо прирікають інших на смерть? Інших? Та нічим изі «інші» не відрізнялися від них. Такі ж прості селюки, хіба щзо, може, майна було більше, хоча...» [Белімова 2014:260]. Письменниця апелює до національної історії, звертається до генетичних рис українців та антропологічного коду.

Артикулюючи життєву історію роману, авторка акцентує увагу на масштабності зображених подій та хронотопі, який розширюється від Києва, маленького села на Черкащині до нацистської Німеччини й далекої Австралії. Химерно переплітаючи долі родин Терещенків з Києва та Єфрема Коломійця 3 села Княжа Криниця на Черкащині, авторка творить сімейну сагу. Життєвий матеріал, що ліг в основу роману «Вільний світ», збігається із біографією самої 
письменниці, історією їі роду. Про це зазначає в інтерв’ю сама авторка: «все, щзо у моєму творі є про Київ, - иче щүоденникові спогади. Тобто, ичей досвіджиття до війни $i$ під час війни, те, як війна змінює все життя, всі пріоритети, всі изінності, як багато чого стає другорядним - певним чином у мене був» [Белімова]. Т. Белімова у романі звертається до історії своєї сім’ї, свідченням чого є записи дідуся іï чоловіка, який і став прототипом Сфрема Коломійця. Безпосередня зустріч з прототипами персонажів твору, «саме у 2013 роц̧і до нас приїхали наші австралійські родичі, нащзадки Жори (героя який після війни не повертається додому, а емігрує в Австралію - ред.). Минулого року приїздила дочка Жори, Таня, про яку йдеться в кінці книги» [Белімова], зворушила авторку, спонукаючи завершити історію родини, розпорошеної по світу. Спираючись на достовірні дані, взяті 3 історії свого роду, Тетяна Белімова експлікує біографічний різновид роману. Реконструюючи минуле, події, людей, письменниця звертається до пам'яток, приватних записів, що є достовірним відбитком приватного життя людини та історії.

Змальовуючи драматичну історію двох українських сімей, авторка фрагментарно подає основні віхи життя персонажів, експлікуючи не тільки сімейні традиції, основи роду, а, перш за все, внутрішній світ особистості. Оповідь у кожному розділі ведеться від імені одного з персонажів - Полі, Нюсі, Клави, Єфрема, Тоні, Жори, Кеті, Марії, Ольги, що дозволяє говорити про сповідальний характер нарації. Тетяна Белімова через спогади персонажів розкриває драматичні перипетії життя, через їх голоси (стилізовані під «внутрішній монолог») передає внутрішній стан душі. Такий тип оповіді визначає координати наративного дискурсу твору, наближаючи його до «потоку свідомості». Оповідь у творі ведеться у хронологічному порядку, проте наявні зміщення - ретроспекція (для увиразнення сюжетних ліній та психологізму) та аналепсис, який через спогад, через деталізацію найбільш яскравих епізодів минулого увиразнює художню картину світу. Своє життя Клава передає декількома штрихами, проте за ними криється іiі біль, іiі радість та щира любов: «Володимир, визначив усе моє життя, розграфив усі його віхи. 
Фах - медична сестра (йому треба було амбулаторне лікування), робота - у туберкульозному диспансері (про ворога треба знати все! i навіть більше!), захоплення - музика (платівки, платівки й платівки - симфонічна - оперна рідкісна у нас джазова)» [Белімова 2014:11]. Заглиблення у внутрішній світ персонажів, передача динамічних дій, що відбуваються в їх душі, наближає твір до психологічної прози. Пам'ять Нюсі, Клави, Єфрема, Ольги, Жори зберігає інформацію з минулого, навіть до дрібниць, намагаючись зафіксувати звуки, голоси, запахи, предмети. Особливості оповідної техніки засвідчують про суб'єктивність відтворення подій, фрагментарність оповіді, сповідальний характер.

Індивідуальна манера письма визначається вмінням письменниці репрезентувати індивідуально-авторський спосіб оповіді, що характеризується фрагментарністю зображення, кінокадровістю, калейдоскопічністю, монтажністю картин. Кожен розділ - своєрідна замальовка, окрема новела, в якій авторка акцентує увагу на невеликому, але важливому епізоді у житті кожного 3 персонажів. Письменниця вдається до новелістичного прийому в романі: подає інтригу, а потім розгортає події. Ніби на магнітофонній плівці записані фрагменти оповідей, спогадів про голодомор, довоєнне життя, остарбайтерів, життя у Радянському Союзі та еміграцію українців, які не хочуть жити в тоталітарній системі. Філософські проблеми буття, проблеми людини у світі, свободи та національної ідентичності $є$ суттєвими ознаками історіософського роману, а наявність екзистенційних проблем буття на межі життя та смерті, проблем вибору, свободи, духовного становлення особистості, що відображає людину в складній ситуації духовного розлому, а також утвердження цінності людської особистості та мотивованості її вчинків [Баканов 1989:98-117].

Метафора «вільного світу» у романі Тетяни Белімової простежується через образи майже всіх персонажів, які прагнуть свободи як внутрішньої, так і свободи у світі, що над ними тяжіє: «Ти знаєи, як воно буває, коли - весь вільний - світ - навколо сходиться в одній людині?» [Белімова 2014:11], «Мурашник? Мурашник. Гігантський, справний, механізований. Так от який 
ти, вільний світе? Ось ти яка, Європо? Така ж знедолена й розчавлена війною, яку сама ж і розпочала? Що важливіше: хто розпочав чи хто завершить?» [Белімова 2014:23]. Як зазначає сама авторка - це авторський сарказм, бо справді, вільними персонажі не почувають себе ніде: ні живучи на рідній землі - в тодішньому Радянському Союзі, бо «радянські люди - повинні чітко розуміти й втілювати своє високе призначення в житті. У нас почуття обов'язку перед Партією й Батьківщиною» [Белімова 2014:244]; ні в Німеччині, куди потрапляють під час Другої світової війни, стаючи остарбайтерами; ні за океаном, куди відправляються у пошуках кращої долі, проте «той вільний світ, якого Тоня так прагнула, став для неї справжньою в'язницею, яку вона носила в собі всі шістдесят років свого життя» [Белімова 2014:234]. Мука й страждання пронизують душі персонажів, тому кожен 3 них прагне позбутися, відпустити цей біль, стати вільним у вільному світі.

Вільним світ не стає ні для Єфрема, який повернувся на рідну землю в надії стати господарем, ні для Жори (Георгія Терещенка), що шукав кращої долі за океаном, у далекій Австралії. Втеча у «вільний світ» для вигнанця-емігранта та остарбайтера, що прагнув будувати такий світ у радянській системі, закінчується пристосуванням до умов суспільства. Єфрем змушений працювати у колгоспі й заробляти трудодні, миритися із системою, хоч мріяв вчитися, здобути певний фах, проте тавро «куркульського сина», неблагонадійного лежало на ньому. Тоталітарна система прагне зламати героя, бо життя «нічого не варте, як і праия в колгоспі» [Белімова 2014:228]. Авторка акцентує увагу не на буднях колгоспника, який повернувся з Німеччини - Єфрема, а на психологічному аспекті, його сприйнятті радянської дійсності: «Воля? Воля... Чи ж иього сподівались, повертаючись?», - запитує себе Єфрем, але відповідь звучить досить невтішна: «Хотіли й тут рай своїми руками розбудувати - для себебатьків - рідних - односельиів... Знали як (чи лише думали, що знаємо), вірили $в$ себе, у те світле майбутне (вірили чи просто дурили себе). «Ти про ту свою Германію забувай, хлопче! Тобі ж краще буде», - i не порада зовсім, а наче 
погроза» [Белімова 2014:228]. Георгій Терещенко, відправляючись за океан, змушений підписати контракт і стати заручником суспільних норм, бо треба два роки відпрацювати на громадських роботах за надане житло, громадянство, проїзд. Адаптація в Австралії призводить до «приборкання - - собi - свого ментального - слов'янського - аж - до - цілковитого - злиття - з - усім тутешнім» [Белімова 2014:231]. Пристосування до нових умов, ностальгія за Батьківщиною, за «зеленим островом дитинства (Труханів острів - С. Ж.)», що часто приходить у сни, підсилюється Шевченковими рядками: «На чужині не ті люде - важко з ними жити! Ні з ким буде поплакати, ні поговорити» [Белімова 2014:232]. Ностальгія Жори пов'язана 3 спогадами про минуле, 3 містом його «дитинства та юності, спогад про який він носив, як найбільшу святиню, завжди ліворуч, там, де серие» [Белімова 2014:249]. Але «зустріч» 3 Києвом приносить Георгію розчарування: місто змінилося, обросло «новою, зроговілою шкірою незграбних забудов», вкрилося «черв'яками висоток», наїжачилося «кам'янииями на Дніпро» [Белімова 2014:249], «тут усе чуже й змінене до невпізнаваності» [Белімова 2014:249].

Переплітаючи людські долі, передаючи внутрішні потрясіння героїв, авторка звертається до проблеми свободи людини у колишньому СРСР та прагне донести, що ні на рідній землі (в тоталітарній державі), ні за океаном герої так і не знаходять сподіваного «вільного світу». Кожен із них вибирає свою волю: для Єфрема - це рідна земля, для Георгія - еміграція, для Тоні бажання красиво одягатися і не повертатися в Україну, для Нюсі - тихе сімейне життя. Авторка прагне донести до читача прості життєві істини: «свобода людини - в ї̈ сериі, бо вільний світ - ие не лише зовнішні принади, можливість робити все, що хочеться. Свобода - ие пери за все відповідальність за своє життя, свої дії, розуміння наслідків, які несе кожен твій крок. Все, що з нами трапляється - ще наслідки нашого ж вибору» [Григорова]. Декодування назви прочитується через внутрішню самосвідомість персонажів, шукання «вільного світу» в душі та суспільстві. 
Своєрідність авторського художнього мислення реалізується через жанровий i стильовий синкретизм, психологізм, що заснований на суб’єктивізмі, передачі внутрішнього світу персонажів, їх думок, переживань, вражень, зумовлених внутрішніми та зовнішніми чинниками. Багатопланове моделювання дійсності, жанрова поліфонія твору свідчить про художню філігранність письменниці у змалюванні історії українських сімей та історії держави. Поєднання рис екзистенційних, психологічних, часово-просторових, осмислення дискурсивної практики нарації дає підстави визначити жанрові дефініції твору Т. Белімової «Вільний світ» як роман-хроніка, роман-спогад, біографічний роман, роман-пам'ять, сімейна сага та історіософський роман. Складаючи дерево роду сімей Терещенків та Коломійців, письменниця пропонує кожному скласти родові дерева сімей, розкиданих по світу, роз’єднаних війною та політичною системою.

\section{БІБЛІОГРАФІЯ}

Баканов 1989 - Баканов А. Современный зарубежный исторический роман / А. Баканов. - К. : Высшая школа, 1989. - 184 с.

Белімова 2014 - Белімова Т. Вільний світ : роман / Тетяна Белімова; передм. С. Філоненко. - Харків : Книжковий Клуб «Клуб Сімейного Дозвілля», 2014. -272 c.

Белімова - Белімова: вільного світу як не було, так і немає досі [Електронний ресурс]. - Режим доступу: http://www.bbc.com/ukrainian/entertain ment/2014/12/141201_book_2014_interview_belimova_az

Бовсунівська 2015 - Бовсунівська Т. В. Жанрові модифікації сучасного роману / Т. В. Бовсунівська. - Харків : Вид-во «Діса плюс», 2015. - 368 с.

Григорова А. «Вільний світ» Тетяни Белімової - роман-пам’ять [Електронний ресурс] / Анна Григорова. - Режим доступу: http://vsiknygy.net. ua/shcho_pochytaty/overview/40907/ 